\title{
Études/Inuit/Studies
}

\section{More bears, less bears: Inuit and scientific perceptions of polar bear populations on the west coast of Hudson Bay Plus d'ours, moins d'ours: perceptions inuit et scientifiques des populations d'ours polaires sur la côte ouest de la baie d'Hudson}

\section{Martina Tyrrell}

Volume 30, numéro 2, 2006

L'influence de Marcel Mauss

The influence of Marcel Mauss

URI : https://id.erudit.org/iderudit/017571ar

DOI : https://doi.org/10.7202/017571ar

\section{Aller au sommaire du numéro}

\section{Éditeur(s)}

Association Inuksiutiit Katimajiit Inc.

Centre interuniversitaire d'études et de recherches autochtones (CIÉRA)

\section{ISSN}

0701-1008 (imprimé)

1708-5268 (numérique)

\section{Découvrir la revue}

Citer cet article

Tyrrell, M. (2006). More bears, less bears: Inuit and scientific perceptions of polar bear populations on the west coast of Hudson Bay. Études/Inuit/Studies, 30(2), 191-208. https://doi.org/10.7202/017571ar

\section{Résumé de l'article}

Les perceptions des Inuit et des scientifiques au sujet des populations d'ours polaires se basent sur différentes épistémologies et différents modes de relation et d'interaction avec les ours polaires. Dans de nombreuses communautés, les quotas de chasse à l'ours ont mené à des conflits à la fois internes et externes. Les Inuit du Nunavut constatent que davantage d'ours polaires se trouvent à proximité de leurs communautés. Les scientifiques soutiennent que la plus grande fréquence des rencontres entre ours et humains est due au rapide changement environnemental qui provoque une diminution, plutôt qu'une augmentation, du nombre des ours. Ces perceptions opposées aboutissent en confrontations lorsqu'il s'agit de la chasse et de la protection des ours. Dans les communautés, des conflits éthiques, sociaux et économiques sont apparus depuis la promulgation du système des quotas à cause de vues divergentes concernant l'attribution des quotas, la chasse sportive et les fins morales d'une telle attention portée aux ours polaires. L'une de ces communautés est Arviat, située sur la côte ouest de la baie d'Hudson. Les gens d'Arviat se sentent particulièrement vulnérables à la présence toute proche des ours polaires tout au long de l'année. Le fait d'inclure des femmes dans la chasse et l'investissement financier que représente une chasse à l'ours provoquent des discussions et des sentiments mitigés chaque année au moment de l'ouverture de la saison de chasse. Bien que la situation à Arviat soit d'une certaine manière unique, elle peut servir d'exemple aux questions et problèmes que doivent affronter les Inuit à travers tout l'Arctique canadien au moment où, de plus en plus, ils ont affaire à des ours polaires sur le pas de leur porte.
Tous droits réservés @ La revue Études/Inuit/Studies, 2006
Ce document est protégé par la loi sur le droit d'auteur. L’utilisation des services d'Érudit (y compris la reproduction) est assujettie à sa politique d'utilisation que vous pouvez consulter en ligne.

https://apropos.erudit.org/fr/usagers/politique-dutilisation/ 


\title{
More bears, less bears: Inuit and scientific perceptions of polar bear populations on the west coast of Hudson Bay
}

\author{
Martina Tyrrell*
}

Résumé: Plus d'ours, moins d'ours: perceptions inuit et scientifiques des populations d'ours polaires sur la côte ouest de la baie d'Hudson

Les perceptions des Inuit et des scientifiques au sujet des populations d'ours polaires se basent sur différentes épistémologies et différents modes de relation et d'interaction avec les ours polaires. Dans de nombreuses communautés, les quotas de chasse à l'ours ont mené à des conflits à la fois internes et externes. Les Inuit du Nunavut constatent que davantage d'ours polaires se trouvent à proximité de leurs communautés. Les scientifiques soutiennent que la plus grande fréquence des rencontres entre ours et humains est due au rapide changement environnemental qui provoque une diminution, plutôt qu'une augmentation, du nombre des ours. Ces perceptions opposées aboutissent en confrontations lorsqu'il s'agit de la chasse et de la protection des ours. Dans les communautés, des conflits éthiques, sociaux et économiques sont apparus depuis la promulgation du système des quotas à cause de vues divergentes concernant l'attribution des quotas, la chasse sportive et les fins morales d'une telle attention portée aux ours polaires. L'une de ces communautés est Arviat, située sur la côte ouest de la baie d'Hudson. Les gens d'Arviat se sentent particulièrement vulnérables à la présence toute proche des ours polaires tout au long de l'année. Le fait d'inclure des femmes dans la chasse et l'investissement financier que représente une chasse à l'ours provoquent des discussions et des sentiments mitigés chaque année au moment de l'ouverture de la saison de chasse. Bien que la situation à Arviat soit d'une certaine manière unique, elle peut servir d'exemple aux questions et problèmes que doivent affronter les Inuit à travers tout l'Arctique canadien au moment où, de plus en plus, ils ont affaire à des ours polaires sur le pas de leur porte.

Abstract: More bears, less bears: Inuit and scientific perceptions of polar bear populations on the west coast of Hudson Bay

Inuit and scientific perceptions of polar bear populations are grounded in different epistemologies, relationships and interactions with polar bears. In many communities, the presence of polar bear hunting quotas has led to both external and internal conflicts. Inuit throughout Nunavut are seeing more polar bears in close proximity to their communities. Scientists argue that the increase in bear-human encounters is due to rapid environmental change, leading to a decrease, rather than an increase, in polar bear numbers. These opposing perceptions result in confrontation regarding the hunting and protection of bears. Within communities, ethical, social and economic conflicts arise with regard to the enactment of the quota system due to differing views on the allocation of the quota, the existence of a sport hunt, and the morality of

Scott Polar Research Institute, University of Cambridge, Lensfield Road, Cambridge CB2 IER, United Kingdom.mt443@cam.ac.uk 
such an intense focus on polar bears. One such community is Arviat, on the west coast of lludson Bay. The people of Arviat feel particularly vulnerable to the year-round presence of polar bears in and near their community. The inclusion of women in the hunt and the cost of undertaking a bear hunt, lead to discussion and mixed feclings about the open hunting season each year. While the situation in Arviat is in some ways unique, it also serves as an example of the questions and concerns facing Inuit across the Canadian Arctic as they increasingly have to deal with polar bears on their doorstep.

Years ago there used to be no polar bears at all or even if there was it was rare to see a polar bear. But today there are too many polar bears (Johnny Karetak. Arviat elder).'

\section{Introduction}

In recent years Arviarmiut ${ }^{2}$ have reported a marked increase in the number of polar bears that they encounter along the coastline and in close proximity to their community. Polar bears can now be seen throughout the year, on the sea ice, along the coastline, and even farther inland. With each passing year, Arviarmiut say more bears are venturing into the small community, leading to growing concerns for the safety of both adults and children. Based on on-going anthropological research conducted in Arviat since 2000, this paper sets out to explore Inuit and scientific perceptions of polar bear populations on the west coast of Hudson Bay and some of the external and internal conflicts that have arisen due to the hunting quota system. Inuit have, for a long time, called for an increase in hunting quotas, based on the greater numbers of bears they are encountering, while biologists have called for a decrease in these same quotas, as they believe these encounters result from the impact of climate change on the bear's habitat. As reactions to the recent hunting quota changes in 2005 have demonstrated, these are contentious issues, leading to frustration and concern on both sides. This paper examines some of these frustrations and explores why Inuit feel that with regard to this issue, the health and well-being of polar bears has been given greater weight and importance than the well-being of humans.

\section{Arviat and polar bears}

The Inuit community of Arviat lies on the west coast of Hudson Bay, in the Kivalliq region of Nunavut. The relationship between Arviarmiut-and indeed all

1 In Okatak (2002).

2 Arviarmiut means 'The people of Arviat." 
Inuit - and polar bears, is complex and multilayered. Bears are admired, feared and respected. They are harvested for their pelts and meat. In communities such as Arviat, they also provide an added economic resource through the trophy hunting that takes place each year.

\section{Polar bear sentience}

Saladin D'Anglure has written of the spiritual relationship between Inuit and polar bears. He points out that the bear is to be found throughout Inuit cosmology and mythology: "We find the bear's presence in the depths of the ocean as well as in the heavens, in all the realms of sea, land and air, in associations with life and the powers of the greatest spirits as well as the weakest humans (the orphans)" (Saladin D'Anglure 1990: 183).

Polar bears, due to their predatory nature, their reliance mainly on marine mammals and fish for sustenance, and their ability to stand upright on two legs, were seen in the past to have a particularly close relationship with humans. In Arviat, bears are accorded sentience and intelligence, and people speak of a close human-bear relationship (Tyrrell 2005). Polar bears are known to attack members of particular families, "down the family line, like a curse," as one Arviat elder told me. He said: "The bears would look out for one particular person. They knew him well." I was also told that if a person survived a bear attack, he or she could expect to be attacked again. However, if someone survived three such attacks, this person would never again be attacked by a bear. Polar bears and Inuit are the top Arctic predators and, therefore, when Arviarmiut talk about hunting bears, they do so in the knowledge that they are engaging with an animal with whom they have much in common and who possesses an intelligence unmatched by other animals.

\section{Human-bear encounters}

Arviarmiut recount, with great frequency, tales of past encounters with polar bears. These encounters occur in a variety of contexts such as when travelling on sea ice, tending fox traps in winter, setting fishing nets on the shoreline in summer, or berry picking during fall on the tundra. Stories are told of dogs being attacked, of Inuit being attacked or killed, and of near escapes. One couple, sleeping in their cabin during summer 2003, awoke during the night to find a bear sticking its head through the window over their bed. Another man reported an attack while he was camping. The bear pawed the top of the tent, in which the frightened man lay. The man's companion distracted the bear by driving his skidoo in circles, allowing the first man to exit the tent and escape the bear. It must be noted that most stories involve bears regarding and then ignoring people. Arviarmiut tell of bears walking past them on the tundra, shoreline or sea ice, or bears swimming in the sea during summer. One man said: "If you leave them alone, they'll leave you alone." At the same time this man acknowledged that "skinny" bears pose a great danger to humans and dogs, due to their unpredictability brought on by hunger. 
Throughout the year in Arviat there are regular polar bears sightings. However, the numbers increase at certain times of year. Locals report bear sightings on radio and $\mathrm{CB}^{3}$, warning of the location, number and condition of bears, and encouraging people to be careful and keep their children close to home. During late October, when the sea ice begins to form, sightings of polar bears close to and in the community become more common. Along the coast, hungry bears awaiting the formation of sea ice are attracted by the smell of beluga whale carcasses left along the shore-line by hunters following the beluga whale migration and harvest in early fall. Bears are frequently seen on the outskirts of the community and at the garbage dump, just a short distance from the edge of town. At this time of year, school is occasionally closed early due to the close proximity of bears. This allows children and adults to return to the safety of their homes in large groups. Likewise, a dance I attended in October 2002 was brought to an abrupt end when it was announced that a bear was wandering the streets on the other side of town and we were advised to return to our homes as quickly as possible in the company of other people.

Throughout late October 2002, like many in the community, I followed the movements of a mother bear and two yearling cubs on the far side of the inlet, and only minutes from the community. They could easily be seen from the Arviat shore and people set up binoculars in their houses, or drove to the end of the community dock in order to take a closer look at the movements of these three animals. When another bear was reported to be on the sea ice close to the cemetery, young and old travelled the short distance to observe the bear from a reasonably safe distance. I joined about 15 other people one afternoon and we watched the bear repeatedly jump into the water from an ice floe, and haul himself ${ }^{4}$ out again. A few days later, I watched through binoculars at the wildlife office as this same bear followed the mother and her cubs across the sea ice on the far side of the inlet.

The bears created an air of excitement in the community in late October. All along the shoreline, people watched the movements of bears. On local radio and $\mathrm{CB}$, the bears were discussed, and when they appeared to be coming closer to town (as they did on quite a few occasions) warnings were immediately sent throughout the community. Once the sea ice had formed, sightings of bears declined considerably, as most bears had moved out onto the sea ice for winter in order to hunt seals. But even in deepest winter occasional sightings were reported. From March, paw prints were once again regularly seen in the snow along the coastline and reports of sightings became common once again. Large paw prints at that time of year are often accompanied by one or two sets of smaller prints, marking the passage of a mother with cubs. Throughout summer and early fall, reports of cabin break-ins are common, and the number of sightings and encounters increases steadily until the sea ice forms once again.

For Arviarmiut the presence of bears is a cause of both excitement and anxiety. In October, prior to the open season for bear hunting, the increased sightings of bears close to the community are cause for much anticipation. People enjoy watching the

4

CB: citizen band radio, used across the Canadian Arctic as an important communication tool.

I was assured by Arviarmiut that this was a young male bear.

194/M. TYRRELL 
bears from a safe distance, and there is constant coming and going to areas where they can be seen. Later, people discuss the bears they have seen, in conversation and via the local radio station. The behaviour of the bears is discussed, as is their appearance, condition, and general well-being.

\section{Bears and the subsistence economy}

Bears also play an important role in the subsistence economy, and in the days and weeks leading up to the hunting season there is ongoing talk of the hunt. The economic rewards for successfully hunting a bear are not insubstantial. In the early part of this decade polar bear hides sold for between $\$ 50-65$ per foot (Freeman 2003: 8). Hunters in Arviat told me they expect between $\$ 500-600$ for a big bear (although this can be offset by the cost of gas, taking time off work and processing the pelt) ${ }^{5}$. An average of $140 \mathrm{~kg}$ of edible meat is obtained from an average sized bear and this has a beef substitution value of \$800-900 (ibid.: 10), and serves as food for both humans and dog teams.

Each November, following the local Inuit hunt, Arviat Hunters and Trappers Organisation (H.T.O.) co-ordinates a trophy hunt. Each year, Arviat hosts five trophy hunters. These five hunters, predominantly from the U.S.A., come to the community each year for approximately ten days each. The hunt employs five local guides, and their five assistants, a different pair for each trophy hunter. Wenzel (2005: 379) has noted that a guide in Clyde River can earn up to $\$ 7,250$ from a sport hunt, as well as substantial monetary and material gifts from satisfied and wealthy trophy hunters. Trophy hunting also provides meat to guides and assistants, as trophy hunters are rarely interested in the meat of the animal (cf. Freeman 2003; Wenzel 2005). Most trophy hunters also spend some time in the community either before or after their hunt, thus further contributing to the local economy by staying at the local hotel or guest house and buying local handicrafts. For both the subsistence and the trophy hunt, polar bears also provide income to a few Arviat women who are employed to scrape and clean bear skins for hunters.

\section{Recent concerns}

Polar bears, therefore, play a role in the economic and social life of the community of Arviat. They are talked about, revered, feared, and form part of the subsistence practices within the community. However, in recent years there have been growing fears regarding the number of bears that are encountered within and close to town. As the opening quote from Johnny Karetak suggests, there is a belief that there are far more bears now than in the old days, and that bear numbers are on the increase. Arviarmiut have noted that these bears often look skinny and unhealthy, and they believe these pose a greater threat to human safety. People feel they must be very cautious not only when venturing out onto land or sea, but also to the outskirts of the community.

5

Arviarmiut rarely keep bear pelts for their own use, but instead sell them to non-Inuit living in, or passing through, the community, or to fur wholesalers in the southern provinces. 
Why does this perception of a greater number of bears exist amongst Arviarmiut? Does it match what scientists are finding with regard to the West Hudson Bay polar bear population? A closer examination of the situation and of Arviat's special position in relation to the community of Churchill will shed some light on the origin of these perceptions.

\section{The Churchill connection}

Canada is home to about half the world population of 22,000 polar bears (Freeman 2003: 2), and of these, approximately 1,200 are to be found in Churchill, northern Manitoba. This small community of 800 residents is situated approximately $250 \mathrm{~km}$ south of Arviat and styles itself as "The polar bear capital of the world." Each fall it attracts 15,000 tourists (CBC News 2004), all descending on the community to view polar bears in their "natural habitat." This polar bear tourism accounts for fully $60 \%$ of the town's economy (ibid.) and, therefore, the continued presence of bears around the community is encouraged. In early fall each year, when bears congregate on the coastline awaiting the formation of sea ice, tourists travel in large white "tundra buggies" to view the bears close up. Polar bear tours are big business in Churchill and some companies are reputed to smear the wheels of their tundra buggies with meat or fish in order to attract bears, while one local entrepreneur is reputed to place beluga whale carcasses at strategic points along the beach in order to attract bears for viewing by tourists. Whether or not these rumours are true, the tourist industry in Churchill relies almost exclusively on polar bear tours ${ }^{6}$. While there have always been bears in the Churchill area, the emergence of the tourism industry has meant that the relationship between bears and humans has changed.

Each year 100-150 cubs are born in the Churchill area (Fikkan et al. 1993: 103). This is perhaps the largest bear population in the world, but also one of the most southerly, which may render the bears particularly vulnerable to environmental/climate change. However, due to the emergence of the tourism industry, and changing environmental conditions, polar bears have become more accustomed to community life and human habitation. Around the community, signs warn of the dangers of polar bears, particularly in areas such as along the rocky beaches. For these hungry bears, who spend the summer fasting as they await the arrival of the sea ice and the opportunity to hunt seals in fall and winter, the presence of humans indicates food and they are particularly fond of the garbage dump on the outskirts of the community. As in Arviat, there are now increased sightings of bears during summer as well as fall. In early July 2003, I witnessed numerous bears wandering around on the outskirts of Churchill. In one afternoon alone, I counted four different bears. On another day, my companions and I reached the Parks Canada site at Cape Merry just hours after a bear had broken down a door and rummaged through a building. Bears, no longer cautious around human habitation, regularly come right into the town and wander the streets.

6 Beluga whale and bird watching are the two other major tourist activities in Churchill, but bring in far less revenue than the more spectacular bear watching tours. 
Some of the bears who spend the summer and early fall in Churchill are considered "rogue bears" and are treated accordingly. While forced movement of bears is prohibited under the terms of the 1973 International Agreement on Conservation of Polar Bears and their Habitat, under Article III there is "an exemption permitting troublesome bears to be captured and transported away from Churchill" (Fikkan et al. 1993: 128). Bears who repeatedly come into the community or are considered a threat to humans, are tranquillised and placed in a holding facility next to the airport, known locally as the "polar bear prison." Before being transported north in nets strung from helicopters and deposited $30 \mathrm{~km}$ away, the bears' foreheads are marked with dye (Struzik 1986: 34). By transporting them farther away, they slowly make their way back to the coast again, by which time the ice has formed and they can move immediately out onto the sea ice. In 2004, 176 bears were relocated from Churchill in this manner (ITV News 2005).

The situation in Churchill provides some background to the relationship between polar bears and Arviarmiut. A large proportion of the bears coming into Arviat carry the dye marks from their capture in Churchill. These are animals that have come to associate human communities with food (particularly from the garbage dump) and are no longer scared away by the sounds of human habitation. Arviarmiut believe that their lives are being put at risk through the presence of these de-sensitised bears on their doorstep. Due to the presence of a strict quota system, Arviarmiut feel that bears are a privileged, protected species while humans are in danger.

\section{Increasing or decreasing bear populations?}

In both Arviat and Churchill, locals say there are many more bears now than in the past. Furthermore, many of the bears Arviarmiut encounter close to and in the community have come from Churchill. Are these growing encounters with bears a reflection of increased bear populations? Or are they a sign that bear populations are in crisis and decline on the west coast of Hudson Bay?

\section{Inuit perspectives}

Throughout Nunavut there is a growing concern regarding the number of bears encountered in close proximity to communities. In an April 2006 CBC radio interview, Nunavut's MP and native of Arviat Nancy Karetak-Lindell said that in summer 2005 she refused to go to one of her favourite summer fishing camps due to the increased presence of polar bears. She said people in Arviat always encountered some bears in fall, but the steadily growing numbers during summer are having a detrimental impact on fishing and other summer subsistence activities.

All Arviarmiut I have spoken to on the subject agree that there are more bears. As in other communities, some people believe this to be the result of conservatively low hunting quotas, allowing bear numbers to grow steadily with each passing year. When I have raised the issue of climate change, the majority of people agree it is an issue of concern for all Arctic inhabitants. However, as one elder told me: "The bears can adapt. 
Look how well they're doing down in Churchill. They get their food from somewhere else now. If they can do it [adapt], we can too." This issue of adaptation was also addressed by Karetak-Lindell in her CBC interview. For many Nunavumiut this move towards centres of human habitation is seen as an adaptation to climate change by intelligent polar bears.

Elsewhere in Nunavut the situation is similar. In recent years, the residents of Pond Inlet, Clyde River, Qikiqtarjuaq, and elsewhere have called for increases in polar bear quotas (Weber 2004). Villagers say there are now so many bears that the streets of their communities are no longer safe. As in Arviat, bears often walk through the streets in fall. Government of Nunavut polar bear biologist Mitch Taylor said of these communities and others: "Right now, the bears are so abundant there's a public safety issue" (ibid.). Many Inuit believe they are the ones at risk from bears rather than the other way around. Bear numbers would appear to be on the increase, and Inuit feel threatened by the increasing numbers of skinny, hungry bears in their communities.

\section{Scientific perspective}

For the past few decades there has been intense scientific study of the polar bears of West Hudson Bay (e.g., Derocher and Stirling 1992, 1995; Stirling and Øritsland 1995). Much of the more recent research examines the impact of climate change on this particularly vulnerable population of bears, who live at the very periphery of suitable polar bear habitat (Derocher et al. 2004; Stirling et al. 1999). In an article for the National Post newspaper, Blackwell (2005) wrote: "Inuit hunters and others say it looks to them like the number of bears is growing, but scientists argue some of the populations are actually in decline, largely because of the impact of global warming on ice floes." Nowhere is this more evident to biologists than amongst the very bears that the people of Arviat and Churchill are encountering. Scientists say that the number of bears in West Hudson Bay has dropped from 1,200 to 950 in recent years as a result of climate change (ibid.). Recently, sea ice has been breaking up earlier each year, providing bears with a shorter length of time in which to build up the vital fat deposits they utilise during the summer to keep them healthy and strong enough to hunt seals once fall/winter arrives (Freeman and Wenzel 2006: 27). Bear biologist Ian Stirling said the Churchill bears are averaging 80-90 kg lighter than they were 15 years ago (CBC News 2004). Break-up in Churchill is now 10-14 days earlier than a couple of decades ago, and in 2004, the bears were forced off the deteriorating ice four weeks earlier than usual. This is of particular concern with regard to cubs, as hungry nursing mothers cannot produce the healthy fatty milk in the quantities required to properly nurture their cubs. As a result, hungry bears now wander through town, attracted by garbage and the smells of human habitation. The majority of bears in the Churchill holding facility are either females with cubs or young inexperienced bears. These are the ones who become hungry enough to risk a trip into town.

Bears in Churchill are especially vulnerable to climate change, living as they do at the southern extremity of suitable bear habitat, and some biologists fear that this subpopulation is doomed due the to rapid and extreme changes taking place in their habitat. Stirling says: "While villages may think they're seeing more bears, it could just 
be that the populations have drifted closer to humans because of the changes in ice formation" (ibid.).

\section{More bears or less bears?}

Inuit and scientists are in agreement on some things. Both agree that there are more bears close to and in communities than there were before. They also both agree that climate change is leading to decreasing sea ice and a shorter seal hunting season for the bears. What they are not in agreement about is the bears' ability to adapt to these changes. For scientists, the presence of bears at garbage dumps and close to humans is a sign that they are in trouble. Inuit see this same behaviour as a form of adaptation, and due to it, bear numbers are actually on the increase.

This highlights the different perceptions held by Inuit and scientists of the status of polar bear populations. For scientists, the bears are believed to be in decline, at risk from environmental change, with their very existence threatened. Inuit, on the other hand, have encountered growing numbers of bears in and around their communities in recent years and attribute this to growing populations instead of habitat change. The quota changes that occurred in 2005 and their subsequent rejection by biologists reflect these different perspectives. However, these recent quota changes acknowledge the concerns of both sides. For Inuit, the quota increase meant that more bears could be hunted during the open season, thus somewhat allaying fears of the risks posed by increased numbers of bears within and around communities. At the same time, a strictly enforced quota system has been maintained which aims to protect what scientists consider to be vulnerable bear populations. The quota system, however, is not without its critics in Arviat (and elsewhere), and will be discussed below.

\section{The quota system}

Many Arviarmiut believe that the polar bear hunting quota system, as it currently stands, offers greater protection to bears than to humans. The quota system and hunting open season also leads to conflict, both within the community and externally. Before examining some of these conflicts I will outline the workings of the quota system and the open season in Arviat.

In 1963, the Government of the Northwest Territories set its first community quotas. The quotas were based on existing records of hides traded (Fikkan et al. 1993: 104 ) and in 1970 the government allowed part of the quota in certain communities to be sold to trophy hunters "under conditions designed to benefit local communities" (ibid.). Between 1962 and 1971 the maximum number of bears taken in one year by Arviarmiut was 12, and the mean annual take was six animals (McEachern 1978: 66). In the mid-1970s, Arviat's first quota was set at four bears per year and by 1978 this had risen to 15 bears, but "occasionally nuisance bears or illegal kills increased the magnitude of the harvest" (ihid.: 182). In the mid-1980s, the Government of the Northwest Territories implemented a flexible quota system in an attempt to better respond to the evolving threats or impacts on polar bears and their habitat. As Freeman 
and Wenzel (2006: 28) point out, "the co-management regimes in place allow annual re-assessment of the quota, which can be increased or decreased depending on the male-to-female ratio of animals taken, and the non-use of tags when a trophy animal is not taken in an authorised hunt."

The most recent changes to the quota occurred in January 2005. Based on a combination of Inuit traditional knowledge and the research findings of Government of Nunavut and independent scientists, the territorial polar bear quota was increased from 403 bears per year to 518 , an increase of $28 \%$ (Wiig 2005: 1814). In Arviat, this signified a quota increase from 20 to 22 bears. This territory-wide quota increase met with praise from Inuit, but mixed feelings and in some cases, outright shock, from many polar bear biologists and such organisations as the U.S. Fish and Wildlife Service. The sub-population in West Hudson Bay was allocated an increase in harvest from 47 to 56 bears (ibid.). However, as already outlined, scientists who have conducted long-term research on this sub-population believe these bears have already experienced substantial changes in body condition and reproductive rates associated with habitat loss due to climate change (Stirling et al. 1999). In June 2005, six months after the announced quota increase, Government of Nunavut biologists involved in the decision to increase the quota changed their thinking and recommended a move in the opposite direction to further decrease quotas (CBC News 2005). In fact, six months after the quota increase was announced, scientists recommended cutting the West Hudson Bay quota to half its previous level. This was no sudden turn around by scientists, but reflected the many years of scientific research conducted on the impact of climate change on the polar bears of the West Hudson Bay coast. If the scientific recommendations were to be accepted, rather than raising the Arviat quota to 22, it would reduce it to 10 . For reasons mentioned above, this would be objectionable to Arviarmiut who believe bear numbers are increasing.

\section{Open season in Arviat}

In Arviat, the law effectively prohibits any shooting of polar bears outside of the regulated open season, which begins on November 1 of each year. If a hunter finds himself in a dangerous situation with a polar bear while away from the community, he is encouraged to fire shots in the air to frighten the bear away. Closer to the community, when a bear is encountered, the wildlife officer or RCMP must be notified and bangers are fired to frighten away the bear. During a radio report in 2002, a Nunavut wildlife officer thanked people for not harvesting bears too early. He said he realised there were a lot of bears around that year (something noted by everyone 1 spoke to), but rather than shooting them and taking the fur, he encouraged people to "shoo" the bears away from places where they should not be! In Arviat, if a hunter is forced to kill a bear in self-defence, he must turn the skin of the animal over to the wildlife officer, although he may keep the meat for subsistence use. The skin of any such bear is then entered into the quota system and another member of the community benefits by winning the bear skin in a community lottery. Many in Arviat feel that, especially away from the community, some hunters take unnecessary risks, as shooting a bear is an offence that must be dealt with through the appropriate wildlife management channels. 
Each October 31, a lottery takes place at Arviat's community hall. Every Inuk over the age of 16 is eligible for inclusion in the lottery. I will discuss here the lottery as it took place on October 31, 2002. At that time the quota for Arviat was 20 bears. The prize was one of 20 "tags" entitling the holder to hunt a polar bear. Of these 20 "tags," five were sold to sport hunters and the remaining 15 went to Arviarmiut ${ }^{7}$. The draw took place in the community hall close to midnight. The first five people to have their names drawn in the lottery were given the choice to sell their tag for $\$ 2000$ to H.T.O., for resale to sport hunters later in the season. All five sold their tags. Earlier in 2002, two bears were killed in self-defence, and at the lottery those drawn sixth and seventh were given the skins of these bears for their own use. This then left 13 bears before the quota was filled. Each tag is valid for 48 hours. Therefore, the first 13 people had 48 hours from midnight (i.e. November 1) to hunt. If unsuccessful in those 48 hours, the hunter must return the tag to H.T.O. and this is passed on to someone else who then has the next 48 hours to hunt a bear and so on. On the night of October 31 , a list of alternate hunters was drawn and each "tag" winner had 48 hour to hunt until the quota was filled. In 2002, the quota was filled in five days.

In the days leading up to the lottery there is a great air of excitement throughout the community with almost non-stop talk about bears. Men and women alike hope they will be lucky in the lottery. Many men grumble about women being in the draw, while others hope their name will be drawn in the first five, thus guaranteeing a prize of $\$ 2000$. October 31 is one of the biggest nights on the Arviat social calendar, and the community hall is crowded with most of the residents hoping their name, or that of someone close to them, will be drawn.

Despite the quota changes that took place in 2005 , the lottery system remains unchanged. The system, as it currently exists, has led to a number of conflicts (cf: Wenzel and Dowsley 2005). As the open season and October 31 lottery draw near each year, discussion on these issues increases. These are generally not concerned with the number of bears allowable in the harvest, but rather have to do with social and economic aspects of the hunting quota system. External conflicts also arise from the quota system. These result from Arviarmiut (and indeed Inuit in other communities) feeling powerless in the face of forces greater than themselves, such as the various national and international organisations that manage and control the hunt. I will deal with each of these issues in turn.

\section{Conflicts}

\section{Cost considerations: success or failure}

In the days leading up to the lottery, most people I spoke to in Arviat told me they would prefer to have their name drawn in the first five, assuring them of $\$ 2000$. Having a name drawn farther down the list provides the hunter with the opportunity to hunt a

In 2005, following the quota changes Arviat still sold five tags to trophy hunters, and the remaining 17 went to local Inuit hunters (Paul Pemik, pers. comm. 2006). 
bear and the social and economic rewards attendant on that. However, many people would rather not hunt bears, due to the high cost involved. Unlike other hunting endeavours, where the hunt is undertaken at a time that suits the hunter and in suitable weather, this strict system pays no attention to the vagaries of Arctic weather or Inuit working habits. For those working in certain types of job, bear hunting can mean the loss of up to two days wages. Polar bear hunting can be an expensive endeavour, with outlays of gas and food (Keith 2005: 44). The unsuccessful hunter returns home at a loss.

For the successful hunter there are yet other considerations and expenses. Of the 13 successful hunters I spoke to in 2002, each one employed a local woman to clean, scrape and, in some cases, sew the skin. These women charge up to $\$ 300$ per skin. This too is a burden on the hunter, and then he or she must, if not making use of the skin at home, attempt to sell the skin to Qablunaat within the community or down south. Pragmatism is paramount in this community where ready cash is often in short supply. Days before the 2002 lottery, one man told me he hoped if his name was drawn it would be in the first five. His name was drawn, but farther down the list, and he successfully hunted a bear. When next I spoke to him he expressed his happiness at having had the opportunity to hunt a bear, despite the financial outlay of the cost of the hunt and having to pay someone to clean the bear for him. Therefore, while people are not unhappy when their names are drawn, most would prefer to be drawn in the first five. Unlike other hunting activities, when the hunter can undertake a hunt at the most suitable time, bear hunting must be done at a specific time laid down by law. People who do not normally hunt become bear hunters through this system where every adult member of the community is included in the lottery. Bear hunting is enjoyable and can be very rewarding, both socially and economically, however, given the choice, many people would prefer the money to the opportunity to hunt.

\section{Women hunters}

Perhaps the biggest conflict I encountered with regard to the polar bear hunt in Arviat concerned the inclusion of women in the lottery. Many men in Arviat feel it is unfair that women are included in what was traditionally seen as the domain of male hunters. I often heard people say the lottery is "unfair." When I asked one man how it might be made fairer, his reply was: "Take out all those women." Another man said: "It's not just old guys who are sore about it, but young guys too. It gives them less of a chance." In 2002, of 13 successful bear hunters, seven were women. However, women who receive bear tags in the lottery always go hunting with male family members and, if they are successful, the bear is family owned, not owned by the woman herself. "If you left it to the women, the bear would probably get away, wounded," one man said. One woman, who went on the hunt in 2002, told me that on the morning of her hunt, a man announced on local radio that he hoped there would be a blizzard as he did not want women to have successful bear hunts. "A woman's work is in the home, so maybe we shouldn't go out," this woman said. A few women expressed the view that having women in the draw is a good thing as it gives them a chance to do something men would otherwise not involve them in. "It's a once in a lifetime chance," one woman said. She believed it is a good thing that the lower age limit is 16. She said: "A lot of 
people never take their kids out and the kids don't have a chance to experience the hunt. So if they get a tag, they have to go--boys and girls."

In general, women in Arviat are involved in hunting only when there are no men available. A man will take his wife whale or seal hunting in summer and fall only when he can find no suitable male hunting partner. Women, in these instances, are a last resort. With polar bear hunting, women have been included in an attempt to make it "fair." However, the inclusion of women in the quota system causes gender friction with in the community. Traditionally, bear hunting was a male domain, and rather than having women participate in ways similar to whale or seal hunting, they are forced to participate in the bear hunt. Some women I spoke to said they would prefer not to join in the hunt, and would rather stay at home than go out with men for a cold and bumpy qamutik $^{8}$ ride. The friction resulting from the inclusion of women in the hunt may not be common to all Inuit communities. In communities on Baffin Island, for example, the inclusion of women in the hunt is seen by hunters in a positive light. The more family members included in the lottery, the greater the chance for a family to share a tag (George Wenzel, pers. comm. 2006).

\section{The commoditisation of polar bears}

The third internal conflict in Arviat has to do with what I would call the commoditisation of bears. When I asked one elder his opinion of the quota system, he said: "We never thought of killing a whole lot of bears before. But when you start to impose something, people want to do it more. So when the laws came in prohibiting people from shooting bears, everyone wanted to do it. Leave people alone and they'll be conservative." This belief is shared by others who feel that the excitement, generated by the quota and lottery system, creates a level of expectation very different to the attitude towards bears that existed in the past. A false sense of polar bears as a scarce resource is created through the quota system and the open season. The excitement generated by the open season is perceived to be not inuktitut- the proper Inuit way. Hunters do not openly express their wishes to harvest other animals as they do with polar bears. Elders believe that this is caused by the forced hunting of bears which takes place over such a short period of time each year. Related to this is the fact that many people hunt bears all at once. In early November there can often be as many as 10 hunting parties in pursuit of the same bear. This is considered to be disrespectful to the bears.

The polar bear trophy hunt which takes place in mid-November each year, and attracts wealthy hunters from down south, is also a cause for some concern, particularly amongst Arviat's elders. Pursuing bears for money and for sport is again viewed as disrespectful and, even though it brings some much needed income into the community, many have mixed feelings about it. Some people say it forces people to think about and talk about bears in inappropriate ways (see Wenzel and Dowsley 2005, for similar concerns regarding inappropriateness amongst Inuit in Clyde River).

8

Qamutik means 'sled.' 


\section{Powerlessness}

All three of these internal conflicts are linked to the fact that it is not locals who set the rules but larger state and international organisations. Emile Immaroitok, an Igloolik elder, said in an interview:

The introduction of the quota system for animals was a very distressing time for the people who had not had to live by this way of conservation for animals. A lot of people did not like the idea in the beginning and it only caused tensions amongst the hunters and that it had a lot to do with having to abide by laws or perhaps even having to go to court for killing certain animals. There was such a case when there were a couple of guys who did have to go to court for 'illegally' killing polar bears one time (Nunavut Planning Commission 2000).

As Merritt (1993: 23) points out, "the issue of wildlife management has often been a sore point in the reactions [sic] between Inuit and the Canadian state." Wildlife laws, he maintains, are often ill-adapted to northern conditions and unconcerned by Inuit customs and practices. This is reflected in Nunavut, where one of the core elements of the Land Claims Agreement was the demand by Inuit for the establishment of a new system of wildlife management. However, an issue such as the protection of polar bears reaches far beyond Nunavut and is based on an international agreement involving five nations. As the United States is a signatory of the Agreement of the Conservation of Polar Bears, the U.S. Fish and Wildlife Service had the right to formally ask Nunavut to clarify its polar bear management policies following the increase of the bear quota in 2005. At present (May 2006) the U.S. government is using that information to determine if polar bears should be placed on their threatened species list, thus denying trophy hunters the opportunity to bring trophies (i.e. polar bear pelts) into the U.S. (CBC News 2005). As Freeman (2003: 4) has pointed out, "domestic legislation in the U.S. is designed, inter alia, to interfere with the jurisdictional authority of other countries by threatening punitive economic sanctions if U.S. environmental decisions are not complied with." This, in effect, impacts on the decisions made in Nunavut with regard to hunting quotas and sport hunting. With regard to the International Agreement on the Conservation of Polar Bears and their Habitat, Wenzel (2005: 384) writes: "This system [...] is one in which Inuit and Nunavummiut neither had original input, nor have significant input." Because it is an international accord, countries, such as the United States and Greenland, "much to the perplexity of Inuit, affect the relationship between Inuk and bear across Nunavut" (ibid.).

For the most part, polar bear quotas are viewed in a negative light by Arviarmiut. Hunters feel the need to continually adapt to the environmental changes taking place around them. Artificial quotas remove these opportunities to be flexible and adaptive. They change the way hunting is conducted, by insisting on the inclusion of people who would not normally hunt, such as women. They create a sense of excitement that is anathema to Inuit relationships with polar bears, and indeed, all animals. Furthermore, they lead to Inuit feeling that they have little or no control over how they live their lives in relation to their own environment. 


\section{Conclusion}

In this paper I have explored the contested issues surrounding the hunting of polar bears, and the differing perspectives on which this contestation is based. Inuit and scientists are in agreement that there are now more bears in proximity to communities than there were in the past. However, their perceptions as to why this is the case differ widely, and from these differences emerge the current conflicts over hunting quotas, the continued viability of polar bear populations, and human safety.

This case study has highlighted some of the issues related to polar bear quotas within the community of Arviat and the differing perceptions of bear populations by Inuit and scientists. Inuit believe that in order to live and hunt safely and successfully, they must have the freedom to adapt to environmental changes, and to make use of the opportunities the environment offers. However, as a result of hunting laws imposed from outside of local communities, Inuit feel they have lost that freedom and, therefore, control over their lives as people who live by and from the sea. The maintenance of a strict quota system during a regulated open season denies Inuit the flexibility to kill bears when they need to. Therefore the bears pose a threat to life within the community and to hunters on the land or sea ice who take unnecessary risks around bears. Furthermore, people who have not hunted bears before or have no desire to hunt them are forced to take part in the hunt as a result of the universal lottery system.

Inuit feel that despite claims to co-management made by the authorities (Freeman 2005: 5), the opinions of local people are ignored and lives are put at risk. Arviat is typical of many Nunavut communities, where the same issues of powerlessness in the face of external control of the hunt, inappropriate and disrespectful relationships with polar bears, perceptions of growing bear populations, and the costs and benefits of bear hunting, arise. This said, the quota system brings some opportunities. The sale of tags to sport hunters allows some to gain a substantial sum of money $(\$ 2000)$, while providing guides and assistants with employment during the hunt itself, and adding income into the community in other ways. The polar bear hunting quota is, therefore, a mixed blessing to the people of Arviat.

\section{References}

BLACK WELL, Tom

2005 U.S. may ban American hunters returning trophies from Nunavut sports hunt, National Post, September 16: A5.

CBC NEWS

2004 The shrinking polar bears (online version at www.cbc.ca/news/background/ polarbears).

$2005 \quad$ Nunavut rethinks polar bear quotas as numbers drop (online version at www.cbc.ca/story/canada/national/2005/01/10/polar-bear-hunt050110). 
DEROCHER, Andrew and Ian STIRLING

1992 The population dynamics of polar bears in western Hudson Bay, in D.R. McCulloch and R.H. Barrett (eds.), Wildlife 200I: Populations, London, Elsevier Science Publishers: 1150-1159.

1995 Estimation of polar bear population size and survival in western Hudson Bay, Journal of Wildlife Management, 59: 215-221.

DEROCHER, Andrew, Nick LUNN and Ian STIRLING

2004 Polar bears in a warming climate, Integrative and comparative biology, 44: 163-176.

FIKKAN, Anne, Gail OSHERENKO and Alexander ARIKAINEN

1993 Polar bears: The importance of simplicity, in O. Young and G. Osherenko (eds.), Polar politics: Creating international environmental regimes, London, Cornell University Press: 96-151.

FREEMAN, Milton M.R.

2003 The growth and significance of polar bear trophy hunting: Communitybased sustainable development in the Canadian Arctic, paper presented at the Third International Wildlife Management Congress, Christchurch, New Zealand, December 2003.

2005 'Just one more time before I die': Securing the relationship between Inuit and whales in the Arctic regions, in N. Kishigami and J. Savelle (eds.), Indigenous use and management of marine resources, Osaka, National Museum of Ethnology, Senri Ethnological Series, 67: 59-76.

FREEMAN, Milton M.R. and George W. WENZEL

2006 The nature and significance of polar bear conservation hunting in the Canadian Arctic, Arctic, 59(1): 21-30.

ITV NEWS

2005 Churchill's polar bears (online version at www.itv.com).

KEITH, Darren

2005 Inuit Qaujimaningit Nanurnut (Inuit knowledge of polar bears): A project of the Gjoa Haven Hunters' and Trappers' Organisation, Edmonton, Canadian Circumpolar Institute Press.

McEACHERN, John

1978 A survey of resource harvesting, Eskimo Point, N.W.T., Delta, B.C., Quest Socio-Economic Consultants Inc. 
MERRITT, John

1993 Marine co-management in the Canadian Arctic: The features and implications of Nunavut, paper presented at the Pacem in Maribus Conference XXI, Takaoka.

\section{NUNAVUT PLANNING COMMISSION}

2000 Akunniq planning region interviews with elders (online version at www.ncp.Nunavut.ca/eng/regions/akunniq/elders).

OKATAK, Billy

2002 Unpublished notes from interviews done for The Ocean's Project, Nunavut Department of the Education, Arviat.

SALADIN D'ANGLURE, Bernard

1990 Nanook, super-male: The polar bear in the imaginary space and social time of the Inuit of the Canadian Arctic, in R. Willis (ed.), Signifying animals: Human meaning in the natural world, London, Routledge: 178-195.

STIRLING, Ian and N.A. ØRITSLAND

1995 Relationships between estimates of ringed seal (Phoca hispida) and polar bear (Ursus maritimus) populations in the Canadian Arctic, Canadian Journal of Fisheries and Aquatic Sciences, 52: 2594-2612.

STIRLING, Ian, Nick J. LUNN and John IACOZZA

1999 Long-term trends in the population ecology of polar bears in western Hudson Bay in relation to climatic change, Arctic, 52(3): 294-306.

STRUZIK, Ed

1986 Predators under the gun, Nature Canada, 15(1): 32-40.

TYRRELL, Martina

2005 Perception, knowledge and use of the sea in Arviat, Nunavut, PhD dissertation, Aberdeen, University of Aberdeen, Department of Anthropology.

WEBER, Bob

2004 Canada: Polar bears stalk Arctic hamlets, CNEWS (online version at cnews.canoe.can/CNEWS/Canada/2004/04/04/408749-cp).

WENZEL, George

2005 Nunavut Inuit and polar bear: The cultural politics of the sport hunt, in N. Kishigami and J.M. Savelle (eds.), Indigenous use and management of marine resources, Osaka, National Museum of Ethnology, Senri Ethnological Series, 67: 363-388. 
WENZEL, George and Martha DOWSLEY

2005 Economic and cultural aspects of polar bear sport hunting in Nunavut, Canada, in M.M.R. Freeman, R.J. Hudson and L. Foote (eds), Conservation hunting: People and wildlife in Canada's north, Edmonton, Canadian Circumpolar Institute: 37-45.

WIIG, Øystein

2005 Are polar bears threatened?, Science, 309: 1814. 